\title{
EDITORIAL
}

\section{Preface for advances in biochips}

\author{
Editor-in-Chief: Zhenqing Li
}

Biochip is essentially a bio-microarray device that can perform hundreds or thousands of simultaneous biochemical reactions. ${ }^{[1,2]}$ It offers the researchers a new way for large-scale genomic, proteomic and functional genomic analyses. The biochips also enable people to quickly screen large numbers of biological analyses for many different purposes, from disease diagnosis to detection of bioterrorism chemical agents. ${ }^{[3]}$ By integrating the microarray or microfluidic systems, a miniaturized laboratory is produced, which is also called Lab-on-a-Chip (LOC). Due to the low cost and fast speed of LOC, it is believed to be one of the most promising technologies in 21th century, ${ }^{[4,5]}$ and thus it is great honor and challenge for me to lead a new journal Advances in Biochips.

Advances in Biochip is a wide-ranging, international peer reviewed open access journal from SyncSci Publishing Group. It publishes a wide range of manuscripts, including Comments, Letters, Technical Notes, Articles, Perspectives, and Reviews. The scope of the journal includes, but not limited to, disease diagnosis, detection of bio agents, DNA microarray, protein array, cell chip, tissue microarray, organ-on-a-chip, lab-on-a-chip, sequencing technology, chemical compound microarray, biosensor, microfluidics. Authors must report experimental results if they submitted a

Received: May 7, 2018; Accepted: May 8, 2018; Published: May 10, 2018

Correspondence to: Zhenqing Li, Shanghai Key Laboratory of Modern Optical System, University of Shanghai for Science and Technology, Shanghai 200093, China; Email: zhenqingli@163.com

Citation: Li Z. Preface for Advances in Biochips. Adv Biochips, 2018, 1(1):1-1

Copyright: (c) 2018 Zhenqing Li.This is an open access article distributed under the terms of the Creative Commons Attribution License, which permits unrestricted use, distribution, and reproduction in any medium, provided the original author and source are credited. research articles. The chips developed by the authors may be applied for sampling, chemical reactions, separations, instrumentation, measurements, or data processing. The editors of Advances in Biochip Journal are committed to rapid peer review, to ensure the timely publication of the highest quality original research, communication and review articles. The papers to be selected shall cover a wide range and encompass the most up-to-date information on the recent development of biochips employed in the fields related to biology or analytical chemistry.

I would like to express my sincere gratitude and deep appreciation to the members of SyncSci Publishing Pte Ltd and to all who contribute to their participation, help and interest in the success of this journal.

\section{References}

[1] Barbulovic-Nad I, Lucente M, Sun Y, et al. Bio-microarray fabrication techniquesa review. Critical reviews in biotechnology, 2006, 26(4): 237-259. https://doi.org/10.1080/07388550600978358

[2] Li Z, Zhao Y, Zhang D, et al. The development of a portable buoyancy-driven PCR system and its evaluation by capillary electrophoresis. Sensors and Actuators B: Chemical, 2016, 230: 779-784. https://doi.org/10.1016/j.snb.2016.02.143

[3] Li Z, Yang R, Wang Q, et al. Electrophoresis of periodontal pathogens in poly (ethyleneoxide) solutions with uncoated capillary. Analytical biochemistry, 2015, 471: 70-72. https://doi.org/10.1016/j.ab.2014.11.002

[4] Lopez GA, Estevez MC, Soler M, et al. Recent advances in nanoplasmonic biosensors: Applications and lab-on-a-chip integration. Nanophotonics, 2017, 6(1): 123-136. https://doi.org/10.1515/nanoph-2016-0101

[5] Daw R, Finkelstein J. Lab on a chip. Nature, 2006, 442(7101): 367. https://doi.org/10.1038/442367a 